Kovács Béla

\title{
A MÁVAG Héja vadászrepülőgép konstrukciós előzményei és korszerüsítésének lehetőségei az olasz Reggiane vadászprogram tükrében m.ress
}

\section{TováBBI OLASZ FEJLESZTÉSEK A RE.2000-ESBöL}

A Caproni-Reggiane Re.2000 Falco I. típusból az első továbbfejlesztés a német DB 601A-1 1175 LE-s soros motor olasz licencével (Alfa Romeo R.A.1000 R.C.41-I Monsone) épített Reggiane Re.2001 Falco II. A gép tervezése 1940ben kezdődött, építése párhuzamosan folyt a magyar honvédség számára épített Héjákéval. A gép prototípusa 1940 júliusában repült először. A gép 1942 májusában Málta fölött esett át a tűzkeresztségen. A rendkívül fordulékony gépből csak 252 példány épült. Volt belőle elfogóvadász, fotófelderítő, vadászbombázó, torpedóvető és éjszakai vadász változat. Az alaptípus fegyverzete az olaszoknál „megszokott” 2 db 12,7 mm-es szinkronizált Breda-SAFAT géppuska volt, később a szárnyba beépítettek 1-1 db 7,7es Breda-SAFAT géppuskát. A vadászbombázó törzse alá akár 100 vagy $250 \mathrm{~kg}$-os bombát is lehetett függeszteni, a gép képes volt zuhanóbombázóként is funkcionálni. (A 640 kg-os bombát csak 2 db Re.2001G/V gépen alkalmazták 1942. augusztus 12-én.)

A Re.2001 Falco II. éjszakai vadász változata esetében hamar rájöttek, hogy a géppuskák elégtelenek a négymotoros angolszász bombázók ellen. Ezért a szárnyak alá a Messerschmitt vadászoknál bevált $20 \mathrm{~mm}$-es Mauser MG 151/20-as gépágyú-gondolákat építettek be. Ilyen fegyverzettel szerelt Bf 109G-4-es vadászon szerezte első győzelmeit a legeredményesebb magyar pilóta, Szentgyörgyi Dezső. Ez a fegyverzet légi harcban nem volt megfelelő, mert rontotta a gép repülési tulajdonságait, de az erősen védett bombázók ellen jól megfelelt. A típus érdekessége, hogy a Reggiane erős, 5 főtartós szárnya el tudta viselni a gépágyú sorozatok reakció erejét. Ez arra vezethető viszsza, hogy az eredeti $\mathrm{P}-35$-ös is úgy készült, hogy a szárnyaiban - pontosan a német gépágyuk felfüggesztési helyén - egy nagy űrméretű géppuskát építettek be, tehát a

15. ábra. A korszerüsített Reggiane Re.2001-est már

R.A.1000 R.C.41-I. motorral szerelték (S.Gy.)

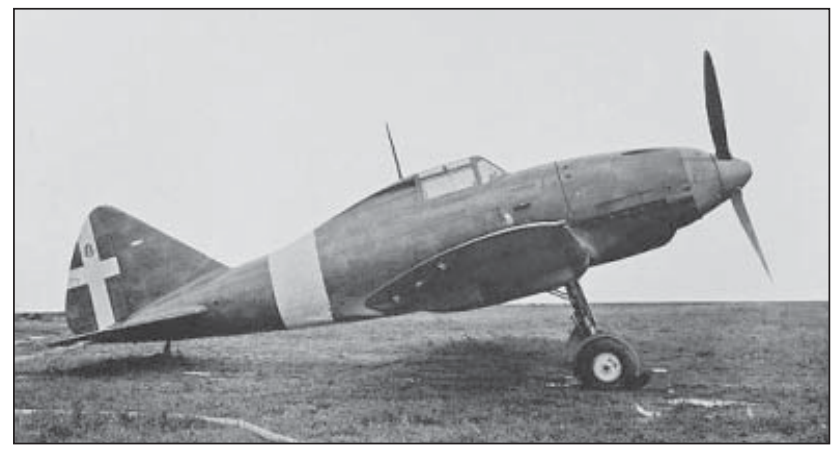

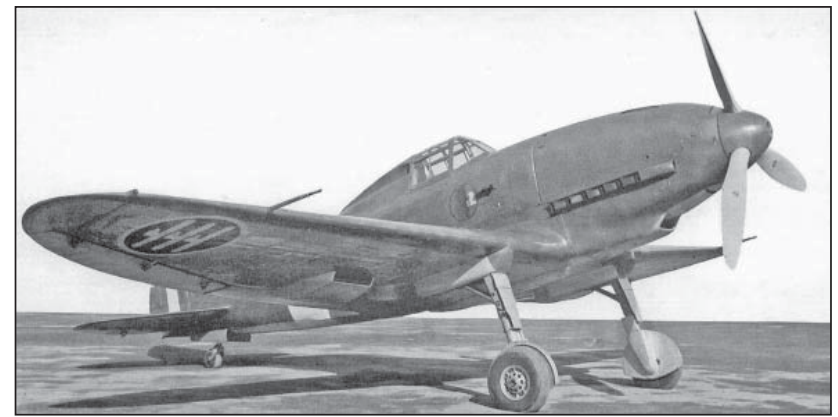

16. ábra. Reggiane Re.2001-es vadászrepülögép (S.Gy.)

szárnyat eleve ilyen erőhatásra tervezték. A Reggiane sorozat már eleve úgy készült, hogy a gépeken kialakították a szárnyfegyverzet helyét.

A Re.2000-esből továbbfejlesztett gépek közül a legjobban a Re.2002-es Ariete hasonlított a kiinduló koncepcióra. $\mathrm{Az}$ Ariete tervezője Roberto Longhi és Antonio Alessio mérnökök voltak, akik 1940-ben a Re.2000-es és Re.2001es gépek terveiből kiindulva egy csatagépet terveztek az 1175 LE-s Piaggio P.XIX R.C.45 Turbine típusú 14 hengeres, kétsoros léghütéses csillagmotorra alapozva. A korábbinál erősebb motor egy 3,1 m átmérőjű háromágú Piaggio P.2001-es légcsavart forgatott. Egy alacsonyan is támadó csatagép számára a víz- és olajhűtővel felszerelt soros motornál, a harci sérülésekre kevésbé érzékeny csillagmotor sokkal megfelelőbb. A gép maximálisan $530 \mathrm{~km} / \mathrm{h}$ sebességet érhetett el, kevesebbet, mint a Re.2000-es, viszont három függesztési pontra összesen $650 \mathrm{~kg}$ tömegü bombát függeszthettek. A bombát mind vízszintes repülésben, mind zuhanórepülésben ki lehetett oldani. A csöves fegyverzete 2 szinkronizált 12,7-es és 2 db 7,7-es BredaSAFAT géppuskából állt. A gépre ledobható póttartályt is lehetett szerelni, maximális repülési távolsága 1100 km

17. ábra. Az olasz fejlesztések csúcsa: a soros motoros Re.2005-ös, a Regia Aeronautica az Olasz Királyi Légierő kötelékében

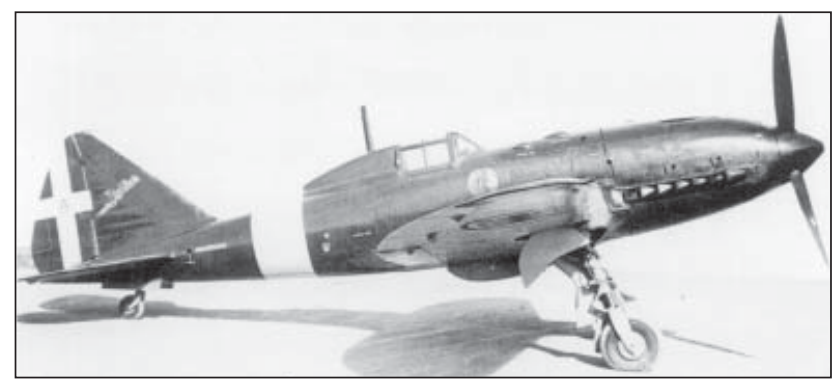




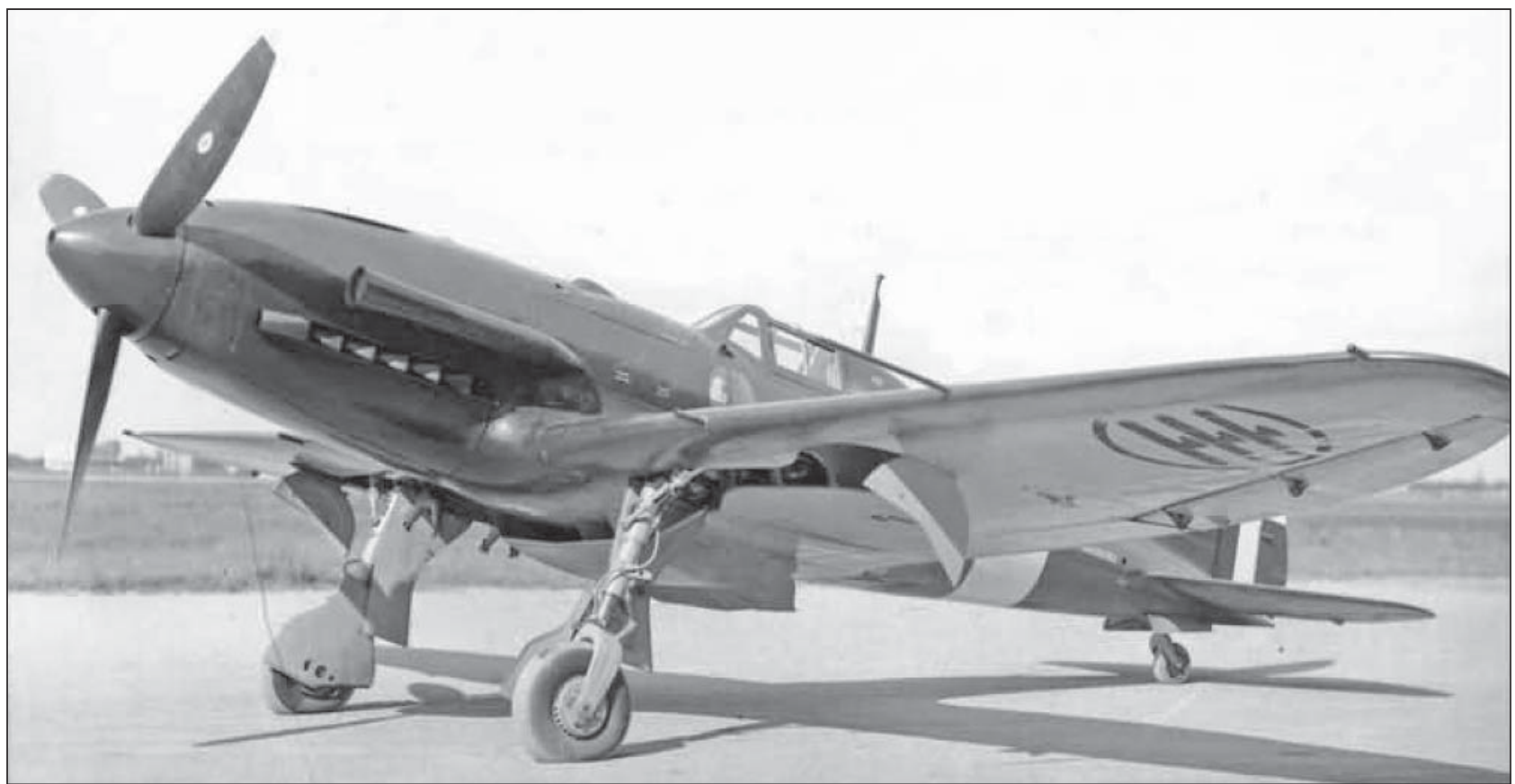

18. ábra. A Reggiane Re.2005 Sagittario a DB-605-ös motorral 630 km/h sebességre volt képes (S.Gy.)

volt. A gépből, három gyárban összesen 225 példány készült. A gép a szövetségesek elleni légi harcokban aktívan részt vett, az olasz fegyverszünet után az átállt légierő is alkalmazta a németek ellen. Azonban a németek kezére is több mint 60 Ariete jutott a gépekből, amelyeket a francia és a jugoszláv partizánok ellen vetették be.

A Re.2001-es és Re.2002-es gépeken kijavították azt a hibát, amely a Re.2000-es Héján sok gondot okozott: a gép repülés közben jelentkező belengését. A két új Reggiane gépen a szárnyközépben kialakított üzemanyagrekeszeket már ellátták hullámtörő falakkal. Ezen kívül a gépek mindkét oldalán praktikus szerelőnyílásokat alakítottak ki, amelyeket zsanéron felfelé nyíló ajtó fedett. Bal oldalon a rádiót pl. egy tálcán lehetett kihúzni, hangolni vagy éppen szerelni. Ez ma is igen fejlett megoldásnak számítana. Korábban ilyen szerelőnyílást a magyar Héjákra a licencadó olasz fél nem engedélyezett, de végül is a páncélozott, frontra küldött olasz gyártású Héja $O$ és a magyar gyártású Héja M gépeken a magyarok kialakították a szükséges praktikus szerelőnyílást a gép jobb oldalán. Az olaszok belátták az elgondolás helyességét és végül maguk is alkalmazták. Az ötlet nem volt új, a kiinduló gépen, a P-35ösön már volt ilyen szerelőnyílás.

A Reggiane fejlesztései közül a Re.2005 típus volt az utolsó, amely szériában épült. A 2 prototípus sikeres berepülése után egy 1000 gépes megrendelés következett, de az olasz átállás és az ország két részre szakadása miatt végül is csak $48 \mathrm{db}$ gép gördült le a szerelősorról, a bombázások miatt mintegy 300 gép nem készült el. A gép a német Daimler Benz DB.605A-1-es, 1475 LE-s motorral vagy az olasz licencével (Fiat RA.1050 RC.58 Tifone) épült. $A z$ első prototípus eredeti német motorral épült és a berepülésen, 1942 júliusában $678 \mathrm{~km} / \mathrm{h}$ sebességet ért el. (A második prototípusba a gép iránt érdeklődő németek egy speciálisan felkészített, gondosan ellenőrzött német motort és német VDM háromágú légcsavart szereltek, amivel a gép, német pilótával, 7300 m-en 720 km/h csúcssebességet ért el. Ezt a legjobb német sorozatgépek még 1944ben is csak beépített befecskendezős gyorsítóval érték el.) A szériagépek olasz motorral és légcsavarral $628 \mathrm{~km} / \mathrm{h}-\mathrm{s}$ sebességre voltak képesek, fegyverzetük is erős volt. A 3 db 20 mm-es Mauser MG 151/20-as gépágyú javadalmazása 2×150 és 200 db lőszer, a 2 db 12,7 mm-es Breda-SAFAT géppuska lőszer-javadalmazása $2 \times 350 \mathrm{db}$ lőszer volt. Ezenkívül a törzse alatt akár egy 1000 kg-os, a szárnyai alatt 1-1 db 160 kg-os bombát hordozhatott. Egy olasz bizottság a 3 konkurens típust, a Macchi C.205-ös, a FIAT G.55-ös és a Re.2005-ös gépeket összehasonlítva a Macchi gépét tette az első helyre. Azonban a pilótavélemény a lefolytatott valós légi harcok után a Reggiane vadászt értékelte a legtöbbre.

\section{A MÁVAG HÉJA KORSZERŰSíTÉSÉNEK ELMÉLETI LEHETőSÉGE OLASZ REGGIANE PROGRAM KORSZERŰSÍTÉSI TAPASZTALATAINAK TÜKRÉBEN}

Összességében megállapítható, hogy a kiinduló típus - a Seversky P-35-ös konstrukciója - három országnak, az USA-nak, Olaszországnak és Magyarországnak adott lehetőséget az akkor korszerűnek mondható vadászrepülőgép-szerkezetek létrehozására.

Áttekintve az olasz fejlesztési sort - a korszerűsített Re.2001 Falco II., a Re.2002 Ariete, illetve a Re.2005 Saggittario típusokat - megállapítható, hogy az olaszok jól kihasználták a Re.2000-es gépben lévő fejlesztési lehetőségeket.

A Reggiane program sikeres vadász-korszerűsítéseinek eredményeivel összefüggésben elméleti szinten érdemes megvizsgálni a magyar MÁVAG Héja korszerűsítésének lehetőségeit is. Fontos erre kitérni már csak azért is, mert a legyártott (legalább) 185 db MÁVAG Héja vadászrepülőgép túlzottan nagy értékű és nagy teljesítményű repülőgép volt ahhoz, hogy mindössze vadász-gyakorló szerepkörben alkalmazza a Magyar Királyi Honvéd Légierő. Pedig ez történt, méghozzá egy olyan helyzetben, amikor a fegyveres küzdelem már hazánk területét érintette (vagy közvetlenül határainkon zajlott).

Fegyverzeti szempontból érdekes számunkra a Re.2001 Falco II. éjszakai vadász változata, amelynél a szárnyak alá 
1. táblázat. A fejlesztett Reggiane vadászrepülőgépek föbb műszaki adatai (készítette: Sárhidai Gyula)

\begin{tabular}{|c|c|c|c|}
\hline & \multicolumn{3}{|c|}{ Típus, név } \\
\hline & $\begin{array}{l}\text { Re.2001 } \\
\text { Falco II. }\end{array}$ & $\begin{array}{l}\text { Re.2002 } \\
\text { Ariete }\end{array}$ & $\begin{array}{c}\text { Re.2005 } \\
\text { Saggittario }\end{array}$ \\
\hline Hosszúság (m) & 8,36 & 8,16 & 8,73 \\
\hline Fesztávolság (m) & 10,98 & 11,0 & 11,0 \\
\hline Magasság (m) & 3,15 & 3,15 & 3,15 \\
\hline Hatótávolság (km) & 1100 & 1100 & $980-1270$ \\
\hline Csúcsmagasság (m) & 11000 & 10500 & 11500 \\
\hline Szerkezeti tömeg (kg) & 2495 & 2400 & 2600 \\
\hline Felszálló tömeg (kg) & 3280 & 3240 & 3610 \\
\hline Max. sebesség (km/h) & 542 & 530 & $628 / 6950 \mathrm{~m}$ \\
\hline Motor & $\begin{array}{l}\text { Alfa Romeo* } \\
\text { R.A.1000 RC.41-I } \\
1175 \text { LE } \\
\end{array}$ & $\begin{array}{c}\text { Piaggio } \\
\text { P.XIX RC 45 Turbine1175 LE }\end{array}$ & $\begin{array}{c}\text { Fiat R.A. } 1050 \text { RC } 58 \\
\text { Tifone }{ }^{\star \star} \\
1455 \text { LE } \\
\end{array}$ \\
\hline Fegyverzet & $\begin{array}{c}2 \times 12,7 \text { mm-es és } \\
2 \times 7,7 \text { mm-es Breda-SAFAT } \\
\text { géppuska }\end{array}$ & $\begin{array}{c}2 \times 12,7 \text { mm-es Breda- } \\
\text { SAFAT géppuska és } \\
2 \times 7,7 \text { mm-es } \\
\text { szárnygéppuska; összesen } \\
650 \text { kg bombateher }\end{array}$ & $\begin{array}{c}3 \times 20 \text { mm-es gépágyú } \\
2 \times 12,7 \text { mm géppuska; } \\
\text { lehetséges } 2 \times 630 \text { kg-os } \\
\text { bomba vagy } \\
1 \times 1000 \text { kg bomba }\end{array}$ \\
\hline
\end{tabular}

* Daimler-Benz DB.601 Aa motor licence, 1175 LE (876 kW) Monsone olasz név alatt, 12 hengeres, fordított V-motor

${ }^{* *}$ Daimler-Benz DB.605A-1 motor licence, 1455 LE (1085 kW) Tifone név alatt.

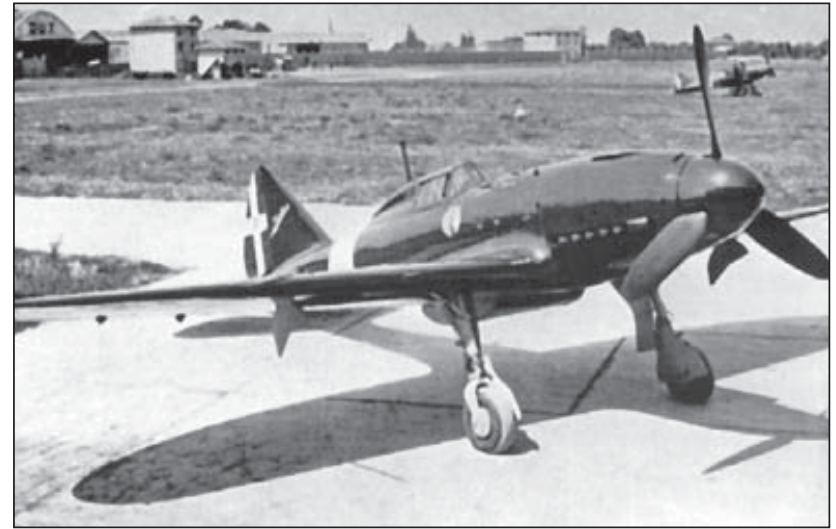

19. ábra. A Reggiane Re.2005 Sagittario DB 605-ös motorjából a magyar hadiipar is gyártott mintegy 1400 darabot (S.Gy.)

szerelt gondolákban 20 mm-es Mauser gépágyúkat intergáltak. Sajnos ezzel a fegyverzeti megoldással nem éltek a magyar licencváltozat gyártásánál. A németek ugyanis nem nagyon akartak eladni a magyaroknak ágyús

20. ábra. A Reggiane Re.2005 Sagittario elölnézete (S.Gy.)

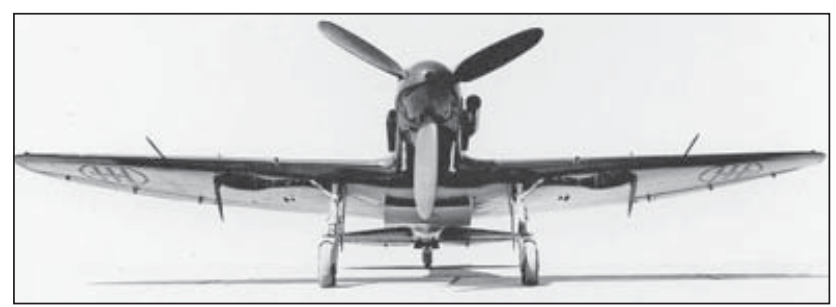

vadászrepülőgépet a német-magyar közös repülőgépgyártási szerződés megkötése előtt. A jó fegyverkereskedelmi kapcsolatok révén azonban Svájcból meg lehetett volna venni akár készen, akár licenc formájában az Oerlikon MGFF 20 mm-es gépágyúját. Ezt építették pl. a Bf 109E vadászokba. A másik svájci fegyver a Hispano-Suiza HS.404-es volt, amelyet ott 3 féle változatban is gyártottak. Francia, angol, amerikai harci gépek használták, teljesítményében talán a német Mauser MG 151/20-asnál is jobb volt. A dolog pikantériája, hogy a japánok híres vadászgépük, a Mitsubishi Zero részére a $20 \mathrm{~mm}$-s gépágyú licencét egy magyar katonatiszttől, Budapesten vásárolták meg az Oerlikon cég képviselőjétől. Nem kellett volna tehát meszszire menni... Mindemellett a győri gyártású Bf 109-esekre fel nem szerelt fegyvergondolákat is fel lehetett volna használni. A Héja $M$ sebessége, az eredeti olasz változatnál

21. ábra. A V.660 oldalszámú kísérleti MÁVAG Héjának csak a roncsáról készült fotó maradt meg. Ezen a gépen $2 \times 250$ kg-os bomba hordozására irányuló zuhanóbombázó kísérleteket folytattak

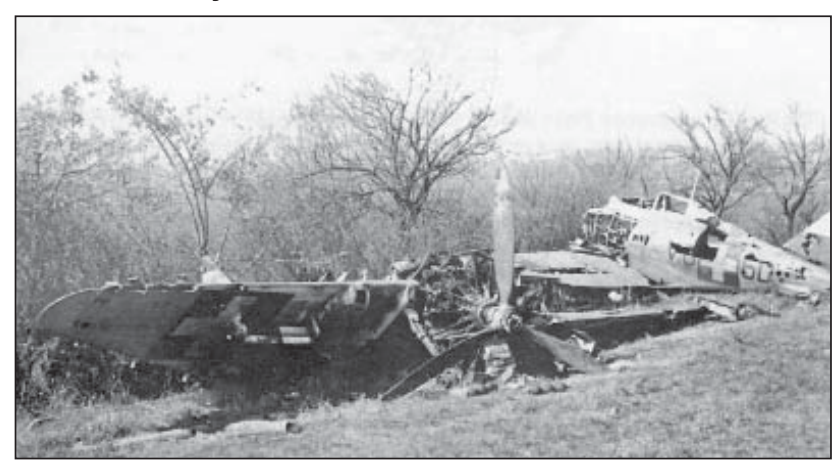




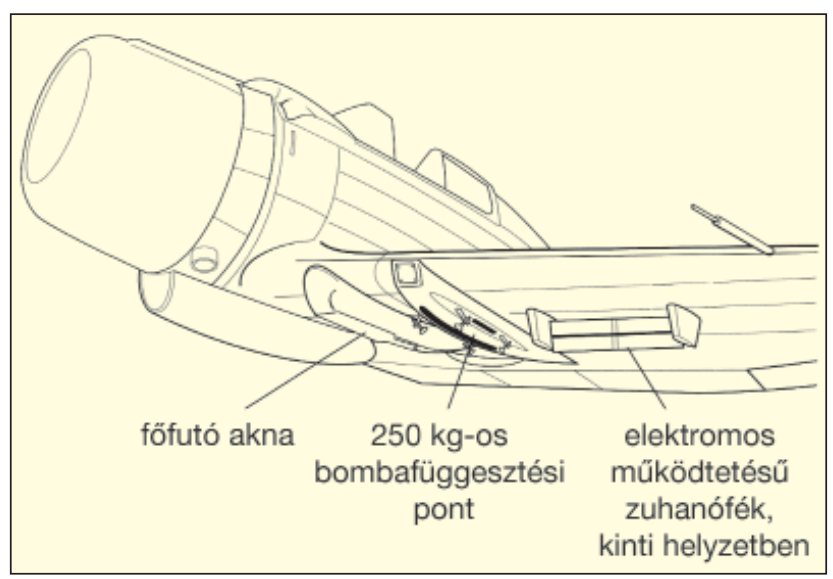

22. ábra. A V.660 oldalszámú kísérleti MÁVAG Héján $2 \times 250 \mathrm{~kg}$-os bombát, valamint a zuhanóbombázó tevékenységhez szükséges zuhanóféklapot szereltek

erősebb motorja elegendő lett volna a lomha bombázók elfogására. A kísérővadászok ellen meg a Bf 109-esek jól megfeleltek volna.

Említésre érdemes még a korszerűsített olasz Reggiane vadászokon - a Re.2002 Ariete, illetve a Re.2005 Saggittario típusokon - megvalósított bombázó és zuhanóbombázó alkalmazás is, amely 630-1000 kg-os bombák hordozásán keresztül valósult meg.

A MÁVAG Héjának létezett kísérleti zuhanóbombázó típusváltozata is. Összesen 2 db zuhanóbombázó Héja épült 1943-ban, a V.560 és V.670 oldalszámú repülőgépek átépítésével. „A légierő kérésére a magyar szakemberek 1943-ban együléses zuhanóbombázót fejlesztettek ki. A dúralumínium héjszerkezetű vadászrepülőgép szárnyrendszerét a zuhanófék és a bombák okozta járulékos terhelés miatt alapos vizsgálat alá vetették. A futóművön kívüli szárnyrészen két-két MWN-típusú német bombafüggesztőt és elbillenő zuhanóféklapokat kellett beépíteni. (A MÁVAG Héja vadászrepülőgépekhez tartozékként járt $4 \mathrm{db}$ bombatár. Ezeken továbbra is alkalmazni lehetett mint az olasz gyártású szériagépeken - a Breda gyármányú felfüggesztőket a 88 db 2 kg-os repeszbomba, vagy 3 kg-os ugyanolyan magyar gyártású bombák számára. Ugyanezen bombatárak felfüggesztési helyére megoldható volt az 50 kg-os bombák felfüggesztésének a kialakítása.) $A$ két repülőgépet átadták a légierőnek. A széria átalakítása az 1944-es bombázásig folytatódott. Több gép nem készült ebben a kivitelben." ${ }^{4}$ A MÁVAG Héja zuhanóbombázó négy bombafüggesztőn 4 db 50 kg-os bomba hordozására volt alkalmas, $600 \mathrm{~km} / \mathrm{h}$ zuhanósebességgel. Hatótávolsága $700 \mathrm{~km}$ volt. A MÁVAG Héja zuhanóbombázó valóban jelentős harcászati képességgel azonban csak akkor rendelkezett volna, ha - az olasz a Re.2002 Ariete, illetve a Re.2005 Saggittario típusokhoz hasonlóan - 500-1000 kg közötti tömegű bomba hordozására lett volna képes. A V.660 oldalszámú gépen $2 \times 250$ kg-os bomba hordozására irányuló kísérleteket folytattak. Ennél a repülőgépnél a centroplánon összesen $2 \mathrm{db}$ bomba-felfüggesztő pontot alakítottak ki, ahová 1-1 db bombát lehetett függeszteni. A magyar fejlesztők azonban a további kísérletekkel végül annak ellenére is felhagytak, hogy az olaszok sikeresen valósítottak meg hasonló jellegű, zuhanóbombázóvá történő átalakítást.

Az olasz korszerűsítési tapasztalatainak tükrében - a Re.2005 Saggittario típus mintájára - felmerülhetett a magyar gyártású DB 605-ös motor beépítésének lehetősége is a MÁVAG Héjába, ami lehetővé tette volna a $630 \mathrm{~km} / \mathrm{h}-\mathrm{s}$ maximális repülési sebesség elérését. A magyar Me $210 \mathrm{Ca}$ és a Me 109G motorja ugyanaz a DB 605-ös erőforrás volt. Magyarország számára 1941-ben a DB 605-ös repülőgépmotor licencösszege 1,7 millió birodalmi márkába (Reichsmark) került. A DB 605-ös motorok gyártása során a Weiss Manfréd Művek csepeli motorgyárában működő üzemrészek két egységét - a végszerelést és a motorpróba-telepet - áttelepítették Horthy-ligetbe (Szigetszentmiklós). Az 1944-es bombázások idején a kőbányai és budatétényi pincékben folyt tovább a DB 605-ös motorok gyártása.

$A 12$ hengeres függő $V$ elrendezésü, $60^{\circ}$-os hengerszögü WM DB 605-ös motorok 2800-as fordulatnál 1475 LE-t tudtak leadni. (Ez a teljesítmény az MW 50-es metanol-víz befecskendező rendszer bekapcsolásával rövid időre 1650 LE-re volt emelhető, és két percen keresztül volt tartható.) A motor tömege $725 \mathrm{~kg}$ volt. A DB 605-ös motorokból 1942ben 10 darabot, 1943-ban mintegy 550 darabot, 1944 novemberéig 650 darabot, a kőbányai pincékben további 178 darabot, összesen mintegy 1388 darabot gyártottak [10]. Ebből 50-100 darab motor valószínűleg beépíthető lett volna a korszerűsített MÁVAG Héja vadász-változatába.

Az olasz példák vizsgálata alapján megkockáztatható a kijelentés: a MÁVAG Héja vadászrepülőgép korszerüsítése a magyar hadiipar és a Magyar Királyi Honvéd Légierő egyik kihagyott lehetősége volt, amit következetesebb haditechnikai kutatás-fejlesztés, illetve az olasz szövetségessel megvalósított szorosabb kutatás-fejlesztési kapcsolattartás mellett könnyen kihasználhattak volna.

\section{ForRÁsOK}

[1] Utijelentés. M. Kir. Honvédelmi Minisztérium 31. osztály. Nemes Janky Béla rep. mérnök szds. 1942. január 16. Közlekedési Múzeum Téma Gyűjtemény 915/976:

[2] William Green: War Planes of the Second World War. Fighters. Volume four 1969. GB. Purnell and Sons London;

[3] Larry Davis: P-35. Squadron/Signal Publication MINI Number 1;

[4] Mikael Forslund-Thierry Vallet: Swedish Fighter Colours 1925-1954. MMPBOOKS. White Series No 9117 Publishe by Stratus, Poland, 2012;

[5] Air Enthusiast Forty-one RE 2000. The 'State-of the Art';

[6] William Green - Gordon Swanborough: Reggiane. The story of an outstanding italian fighter of the 'thirties, 1989 Pilot Press Ltd.;

[7] Kimutatás a V-667 jelű MÁVAG „Héja” rep.-gépbe beépített műszerek és felszerelésekről + Szállítólevél + Hiányjegyzék, MÁVAG. Budapest, 1944. július. Közlekedési Múzeum Téma Gyüjtemény 174/36/2;

[8] Kováts Lajos: Sólymok Héják Nebulók, MAHIR, 1990

[9] Gregory Alegi: Reggiane Re 2005, Ali d'Italia, La Bancarella, Torino, 2001;

[10] Vajda Ferenc Antal: A DB 605 repülőgépmotor Haditechnika, 1987 évi 1. sz. 32-33. o.;

[11] Bonhardt - Sárhidai - Winkler: A Magyar Királyi Honvédség fegyverzete és felszerelése. Zrínyi katonai Kiadó, Budapest;

[12] Punka György: Reggiane Fighters in action. Squadron Signal Aircraft Nr 11.

\section{JEgYZET}

4 Bonhardt - Sárhidai - Winkler: A Magyar Királyi Honvédség

fegyverzete és felszerelése. Zrínyi katonai Kiadó, Budapest, 389. o. 